\title{
Technical Efficiency and Determinants of Maize Production by Smallholder Farmers in the Moneragala District of Sri Lanka
}

\author{
Mohamed Esham \\ Department of Agribusiness Management, Faculty of Agricultural Sciences, \\ Sabaragamuwa University of Sri Lanka, P.O. Box 02, Belihuloya, Sri Lanka \\ Email: esham@susl.lk
}

\section{Doi:10.5901/mjss.2014.v5n27p416}

\begin{abstract}
Maze (Zea mays L.) is the second most important cereal crop after rice produced in Sri Lanka. The government of Sri Lanka has taken steps to expand maize production in the country. In the context of these initiatives; this paper analyzes empirically the technical efficiency of smallholder maize farmers in Sri Lanka using a stochastic frontier production methodology. A sample of 130 maize farmers belonging to four local administrative divisions of the Moneragala district was randomly selected. A wellstructured, comprehensive interview schedule was used for data collection. The findings of the study revealed that the seeds, hired labor and land extent were found to positively influence maize production. The mean technical efficiency was $72 \%$, implying that there was considerable room for improvement in maize productivity within the present state of technology. Access to hybrid maize seeds, age of farm household head and ownership of irrigated lowland were found to be significant factors determining production efficiency at the farm level. Policy implications drawn from the results include setting up of a mechanism to revamp farmer collective action through the formation of farmer groups so that smallholder land consolidation would be possible and interventions towards improving local production of high quality hybrid maize seeds in order to make them available to farmers at an affordable price. Moreover, the government should support the private sector to expand the existing contract farming schemes to remote rural areas.
\end{abstract}

Keywords: Maize; stochastic frontier production; Smallholder farmers; Sri Lanka

\section{Introduction}

Maize (Zea mays L.) is a coarse cereal produced predominately in the dry zone of Sri Lanka. It is second only to rice in terms of total cereal cropped area in the country. Maize occupies 5.6\% of the total cereal cropped area in the country. In the last six years (from 2007 to 2012), maize production has yielded compelling success with the adoption of hybrid seed that has significantly increased smallholder maize production and the area cultivated by $258 \%$ and $73 \%$ respectively (FAOSTAT, 2014). Maize has assumed importance as an input to the growing livestock feed industry, especially for the poultry sector. Moreover, the consumption of maize based food items like locally produced ready-mix cereals (Thriposha and Samaposha), popcorns and boiled maize cobs have increased during the past few years. As a result, the local demand for maize has significantly increased during the past few years. Up to 2008, the bulk of the local requirement was met through imports. However, with the improvement in production, imports have significantly dropped; in 2011 only 8,244 metric tons were imported as against 83,195 metric tons imported in 2008 (Livestock statistical bulletin, 2012). Currently, Sri Lanka has achieved near self sufficiency in maize thus, saving valuable foreign exchange. The private sector has played an important supportive role in this endeavor as a number of private sector companies are taking an active role in promoting maize production. These companies are mainly contributing through contract farming arrangements, where inputs, including hybrid seeds and loan facilities are made available to farmers and the produce is purchased by the companies (Esham, 2009).

A significant number of farmers practicing shifting cultivation as their livelihood have taken-up to intensive maize cultivation, particularly in the dry zone district of Moneragala, where this study was conducted. It is of interest to policy makers, development planners and other stakeholders to understand how these backward smallholder farmers are performing in light of the noteworthy developments in the maize production sector as it is often argued that smallholder poor farmers in developing countries are left out from agricultural development initiatives (Weatherspoon and Reardon, 2003; Singh, 2002; Key and Runsten, 1999; Korovkin, 1992).

In this context, the objective of the current study is to attempt an empirical evaluation of the technical efficiency achieved by maize farmers in the Monergala district by using the stochastic frontier production model. The analysis is 
expected to illustrate the possible efficiency-associated issues and provide empirical evidence, which will enable to assess the current status of the maize production drive of the government as well as to assist policy makers in forming suitable strategies to increase the involvement of the poor smallholder farmers in this important national cereal crop production drive.

\section{Materials and Methods}

\subsection{Study area and data collection}

The study was conducted in the Moneragala district in the Uva province of Sri Lanka. The district is located in the dry zone of the country receiving an annual average rainfall of about $1000 \mathrm{~mm}$. The main rainy season is from September to early January. Major crops grown in the district are paddy and maize. Maize is cultivated as a rain-fed crop during the Maha season (wet season) from October to March. Moneragala is the second largest district in the country producing maize, in 2009/2010 Maha season 13,500 hectares of maize were cultivated in the district, accounting for $28 \%$ of total land extent cultivated in the country.

A sample of 130 maize cultivators belonging to four local administrative divisions of the Siyambalanduwa divisional secretariat division of the Moneragala district was randomly selected. The Siyambalaanduwa Divisional Secretariat Division (DSD) was purposely selected to cover backward maize farmers in the district as it is the DSD with the highest poverty in Sri Lanka. Moreover, a majority of farmers in the DSD cultivates maize. The sampling frame of the maize farmers was prepared based on information obtained from the local administrative officers. A well-structured, comprehensive interview schedule was used for data collection. The data were collected through face-to- face interview with the household heads. This schedule contained questions on demographics, crop production, cost of production and returns, labor utilization, farm management, farm credit and farm investment. The data covers the 2009/2010 Maha season. For the analysis, data from 104 questionnaires were used as other questionnaires were either incomplete or contained inaccurate information.

\subsection{Theoretical and analytical framework}

The stochastic frontier production model proposed by Battese and Coelli (1995) was used to determine the efficiency of the smallholder maize farmers as it is extensively used in farm-specific efficiency studies. According to Battease and Coelli (1995), the stochastic production frontier is expressed as:

$$
\ln Y_{i}=\beta_{0}+\sum_{j=1}^{x} \beta_{j} \ln X_{i j}+v_{i}-u_{i}
$$

Where $Y_{i}$ is the per hectare value of maize output in Rs (Sri Lankan Rupees) for the $i$-th farmer. $X_{i j}$ is the $j^{\text {th }}$ input $(j$ $=1-5)$ used by ith farmer. $X_{1}$ represents seed cost(Rs/ha); $X_{2}$ is the fertilizer cost (Rs/ha); $X_{3}$ refers to the labor cost (Rs/ha); $X_{4}$ is the land extent cultivated with maize (ha); $X_{5}$ represents the cost of the machinery (Rs/ha); In represents the natural logarithm. $\beta_{0}$ and $\beta_{j}$ are unknown parameters to be estimated, $v_{i}$ is a random error term representing measurement errors and other random factors outside the control of the farmer. It is assumed to be independent and identically distributed (iid) following a normal distribution with a zero mean and variance $\sigma^{2}$, while ui is a non-negative random variable that captures technical inefficiency in production assumed to be independently distributed and follows a truncated (at zero) normal distribution with mean, $\mu_{\mathrm{i}}$ and variance $\sigma^{2}$, where $\mu_{\mathrm{i}}$ is defined as:

$$
\mu_{i}=\delta_{o}+\delta_{1} Z_{1 i}+\delta_{2} Z_{2 i}+\delta_{3} Z_{3 i}+\delta_{4} Z_{4 i}+\delta_{5} Z_{5 i}+\omega i
$$

Where, $Z_{1 i}$ shows the age in years; $Z_{2 i}$ represents education in number of schooling years; $Z_{3 i}$ represents family labor (in number); $Z_{4 i}$ is a dummy variable indicating the use of only hybrid seeds; $Z_{5 i}$ represents a dummy variable for ownership of irrigated lowland. The $\delta s$ are unknown parameters to be estimated. wi is an error term, independent and identically distributed and obtained by truncation of the normal distribution with zero mean and constant variance $\sigma^{2}$.

The stochastic frontier production function and the inefficiency model defined by equations (1) and (2) are simultaneously estimated by using the FRONTIER version 4.1, software developed by Coelli (1996). The variance parameters are expressed in terms of $\gamma=\sigma_{u}{ }^{2} /\left(\sigma_{u}{ }^{2}+\sigma_{v}{ }^{2}\right)$, the $\gamma$ parameter lies between zero and one. 


\section{Results}

\subsection{Descriptive statistics}

The Table 1 provides Summary statistics of output and input variables for maize production used in the stochastic frontier production and the inefficiency effect model. The average value of maize output is about Rs. 72,388 per hectare, which results from an average yield of about 2.4 tons, slightly less than the national average of 2.6 tons per hectare (Department of Census and Statistics of Sri Lanka, 2014). Among the input costs consisting of labor, seeds, fertilizer, machinery, the labor cost is the highest cost contributing to the cost of production. The average extent of maize cultivated is $0.74 \mathrm{ha}$, implying that the farmers are smallholders.

The average farm household has five members ranging from a minimum of two members to a maximum of 11 members. A typical household has two adults and three children and in some instances the extended families also live in the household. The average farmer household head was middle aged with an average age of 47 years, ranging from a minimum age of 24 years to a maximum age of 70 years. The majority of the farmers had completed primary education with 7 years of schooling. A typical household has two adults and three children and in some instances the extended families also live in the household. It is common for the husband and the wife to involve in farming, while in most cases, one of the adult children is also involved in farming. Hence, the family labor available for farming is between two and three members.

About $73 \%$ of the interviewed farmers used entirely hybrid seeds in their cultivation, while the rest used a mix of hybrid and local seeds. This clearly show that a considerable number of smallholder farmers in the area have adopted hybrid seeds. Less than half of the interviewed farmers owned irrigated lowlands, in which they cultivated paddy.

Table 1. Variables used for the analysis

\begin{tabular}{lcc}
\hline & Unit & Mean \\
\hline Variables in the production function model & & \\
\hline Gross income $\left(Y_{i}\right)$ & $R s$ & 72387.90 \\
Purchased seed cost $\left(X_{1}\right)$ & $R s$ & 6375.20 \\
Fertilizer cost $\left(X_{2}\right)$ & $R s$ & 9888.12 \\
Hired labor cost $\left(X_{3}\right)$ & Rs & 12837.10 \\
Extent cultivated $\left(X_{4}\right)$ & $R s$ & 0.74 \\
Machinery cost $\left(X_{5}\right)$ & & 9851.85 \\
\hline Variables in the inefficiency model & Years \\
\hline Age of household head $\left(\delta_{1}\right)$ & Years & 46.8 \\
Level of education $\left(\delta_{2}\right)$ & Persons & 7.2 \\
Family labor $\left(\delta_{3}\right)$ & Dummy & 2.3 \\
Use only hybrid seeds $\left(\delta_{4}\right)$ & Dummy & 0.73 \\
Ownership of irrigated lowland $\left(\delta_{5}\right)$ & 0.42 \\
\hline
\end{tabular}

\subsection{Hypotheses test}

The estimates of the variance parameters $\sigma^{2}$ and $y$ are presented in the Table 2. The ratio-parameter, $\gamma=\sigma_{u}{ }^{2} /\left(\sigma_{u}{ }^{2}+\sigma_{v}{ }^{2}\right)$, is significant at the $1 \%$ level, implying that farm specific technical efficiency is important in explaining the total variability of maize output produced. Moreover, the corresponding variance ratio parameter $y$ implies that $90 \%$ of the differences between the observed and the maximum frontier output of maize are due to the existing differences in efficiency levels among farmers.

Prior to examining the parameter estimates of the production frontier and the factors that affect the efficiency, the validity of the efficiency model was tested by employing the log likelihood ratio test statistics, $\lambda$ defined as $\lambda=-2\left[\operatorname{Ln}\left(\mathrm{H}_{0}\right)\right.$ - $\left.\operatorname{Ln}\left(\mathrm{H}_{1}\right)\right]$, where $\operatorname{Ln}\left(\mathrm{H}_{0}\right)$ and $\operatorname{Ln}\left(\mathrm{H}_{1}\right)$ are the log likelihood functions of half normal and truncated normal distributions of technical inefficiency effects. As shown in Table 2, the first hypothesis test which specifies that inefficiency effects are not stochastic is rejected affirming that data warrants a stochastic production function. The second hypothesis specify that technical inefficiency effects are absent from the model, implying that smallholder maize farmer are efficient and there is no room for productivity improvement. This hypothesis is rejected justifying inclusion of inefficiency effects into the model. The third hypothesis test is rejected in favor of the inclusion of famer specific variables in the model. Finally, the fourth hypothesis test, which assesses the joint effect of variables on technical inefficiency, is rejected implying that joint effects 
are statistically significant.

Table 2. Likelihood-ratio tests

\begin{tabular}{ccccc}
\hline Null hypothesis & Log likelihood & LR statistics & Critical value & Decision \\
\hline $\mathrm{H}_{0}: \gamma=0$ & -151.60 & 107.30 & 11.07 & Reject $\mathrm{H}_{0}$ \\
$\mathrm{H}_{0}: \gamma=\delta_{0}=\delta_{1} \ldots . . \delta_{5}$ & -175.20 & 154.50 & 18.31 & Reject $\mathrm{H}_{0}$ \\
$\mathrm{H}_{0}:=\delta_{0}=\delta_{1} \ldots \ldots . \delta_{5}$ & -155.19 & 114.48 & 11.07 & Reject $\mathrm{H}_{0}$ \\
$\mathrm{H}_{0}:=\delta_{1} \ldots \ldots \ldots \ldots \delta_{5}$ & -241.67 & 287.46 & 12.59 & Reject $\mathrm{H}_{0}$ \\
\hline
\end{tabular}

\subsection{Production frontier estimates}

The maximum likelihood estimates (MLE) for the parameters of the Cobb Douglas stochastic frontier production model for the maize farmers are given in Table 3. The results suggest that purchased seeds, hired labor and the land extent of maize cultivation are having a significant influence on maize crop income hence productivity of maize. Land extent is the most significant factor of production with an elasticity of 0.658 , which implies that, an increase in the extent of land under maize cultivation would significantly lead to increased maize output or $1 \%$ increase in land extent will lead to increase in maize output by $0.66 \%$. This indicates that by expanding the scale of the operation further increase in productivity would be possible. Purchased seed cost is statistically significant; it is because hybrid seeds are costly and farmers usually do not use the recommended rate of seeding. Hired labor is the other input that is statistically significant as labor is a significant input in the production of maize. This is due to the production of maize in the area is done in the absence of farm mechanization and use of traditional technology that relies heavily on labor. The sum of input elasticities is close to unity implying that maize is produced near to constant returns to scale by the sample farmers.

Table 3. Technical efficiency and determinants

\begin{tabular}{|c|c|c|}
\hline \multirow{2}{*}{ Variables } & \multicolumn{2}{|c|}{ ML estimates } \\
\hline & Coefficient & t-ratio \\
\hline \multicolumn{3}{|l|}{ Stochastic frontier model } \\
\hline Constant & $9.957^{\star \star *}$ & 45.655 \\
\hline Purchased seed cost & $0.132^{\star *}$ & 1.942 \\
\hline Fertilizer cost & 0.010 & 0.309 \\
\hline Hired labor cost & $0.122^{\star \star}$ & 1.988 \\
\hline Land extent cultivated & $0.658 * * *$ & 3.898 \\
\hline Machinery cost & -0.006 & -0.433 \\
\hline \multicolumn{3}{|l|}{ Technical inefficiency model } \\
\hline Constant & $-9.060 * * *$ & -2.673 \\
\hline Age of household head & $0.094^{\star \star}$ & 1.984 \\
\hline Level of education & -0.075 & -0.496 \\
\hline Family labor & -0.276 & -0.519 \\
\hline Use only hybrid seeds & $-1.292^{\star \star \star}$ & -3.560 \\
\hline Ownership of irrigated lowland & $-0.871^{\star \star \star}$ & -2.632 \\
\hline \multicolumn{3}{|l|}{ Variance parameters } \\
\hline Sigma-square $\left(\sigma^{2}\right)$ & $12.391^{\star \star *}$ & 4.595 \\
\hline Gamma $(\gamma)$ & $0.902^{\star \star \star}$ & 37.308 \\
\hline Ln Likelihood & -99.165 & \\
\hline
\end{tabular}

\subsection{Determinants of technical inefficiency}

The MLEs for the parameters of the technical inefficiency model are also presented in Table 3. The estimated coefficients of the explanatory variables in the model for the technical inefficiency effects are of interest and have important implications. A negative sign on a parameter explaining inefficiencies means that the variable is improving technical efficiency, while for a positive sign, the reverse is true. The results indicate that age of household head, ownership of irrigated lowland and the use of only hybrid maize seeds are significant determinants of the technical efficiency of maize production. The age of the household head is positively significant, implying that the younger maize farmers are more 
productive than the older farmers. This is due to the young farmers are more inclined to adopt new technologies than the older farmers. A negative sign on the dummy variable for purchasing hybrid seeds indicates that the use of hybrid seeds is a major contributor to technical efficiency. This variable is statistically significant at one percent. Despite the gains in technical efficiency, only 73 percent of the farmers used entirely hybrid seeds. This is because of high prices for hybrid seeds, making them unaffordable to some farmers. Ownership of irrigated lowland is negatively significant, indicating that farmers who cultivate paddy under major or minor irrigation systems are more productive than those who do not own lowland to cultivate paddy. This is probably because these farmers are better off financially, so that they could afford to purchase hybrid seeds and other inputs. These findings confirm that resource poor farmers are left out of agricultural development initiatives as revealed by many studies in developing countries (Weatherspoon and Reardon, 2003; Singh, 2002 ; Key and Runsten, 1999 and Korovkin, 1992).

\subsection{Frequency distributions of technical efficiency estimates}

The Frequency and percentage distribution of technical efficiency measures are summarized in the Table 4. The mean value of technical efficiency is estimated to be $72 \%$, with a range from $21 \%$ to $95 \%$. The results indicate that about half of the farmers operate below $70 \%$ efficiency level. Thus, there is considerable room for improvement in the technical efficiencies of maize production. It shows that output can be increased on average by $28 \%$ with the present state of technology and without the need for additional inputs provided the technical inefficiencies are removed completely. The mean technical efficiency is lower than those reported by previous frontier studies of maize production in South Asian region. For example, technical efficiency levels of $77 \%$ in India, $91 \%$ in Bangladesh and $94 \%$ in Pakistan, was reported by Anupama et al., (2005), Rahman et al., (2012) and Naqvi and Ashfaq (2013) respectively.

Table 4. Frequency and percentage distribution of technical efficiency

\begin{tabular}{ccc}
\hline Efficiency range & Frequency & Percentage \\
\hline Less than 51 & 16 & 15.38 \\
$51-60$ & 14 & 13.46 \\
$61-70$ & 19 & 18.27 \\
$71-80$ & 35 & 33.65 \\
$81-90$ & 18 & 17.31 \\
$91-100$ & 2 & 1.92 \\
Total & 104 & 100 \\
Mean & $72 \%$ & \\
Maximum & $95 \%$ & \\
Minimum & $21 \%$ & \\
\hline
\end{tabular}

\subsection{Loss due to inefficiency and potential maize output}

The value of potential maize output is estimated by dividing the actual value of output by the mean technical efficiency. The value of lost output is the difference between the value of potential maize output and the actual value of maize output. The Table 5 shows the values of potential maize output and the output lost due to technical inefficiency. It is clear that a substantial loss of maize output worth of Rs. 28,151 is incurred per hectare by farmers due to technical inefficiency. This loss can be minimized through better utilization of resources which are at the disposal of the farmers.

Table 5. Estimated value of potential output and value of output lost due to technical inefficiency

\begin{tabular}{lc}
\hline Technical efficiency & Value of maize (Rs) \\
\hline Actual value of output (Rs/ha) & $72,387.90$ \\
Potential value of output (Rs/ha) & $100,387.75$ \\
Value of loss of output due to inefficiency (Rs/ha) & $28,150.85$ \\
\hline
\end{tabular}




\section{Discussion}

Given the emphasis placed by the government of Sri Lanka on improving maize production, this study is undertaken to provide insights on economic aspects of maize production to policy makers, extension agents and the private sector participants engaged in the maize production drive. The results of the study indicate that the land holding size is a crucial aspect influencing productivity. As the agricultural sector in Sri Lanka is dominated by smallholder farmers, the small farm size is most of the time a limiting factor. Other studies on productivity of crops in Sri Lanka such as for rice (Shantha et. al., 2012), tea (Basnayake and Gunaratne, 2002) and Potato (Amarasinghe and Weerahewa, 2001) has revealed that land is a significant factor of production. In this regard, consolidation of fragmented smallholder land holdings through collective farming or group farming would be a feasible option for consideration to reap the benefits of economies of scales in maize production. Moreover, collective farming will enable farmers to mechanize their farming operation as well as access to modern farm equipments and facilities otherwise not affordable to them due to high capital outlays involved in purchasing them. Another important factor that influences maize productivity is the access to high quality hybrid maize seeds. The farmers in backward farming areas such as area where this study was conducted are not financially sound to purchase expensive hybrid seeds as most of these seeds are priced high as it is imported into the country by private sector companies. It is vital to streamline local hybrid seed production program to ensure the availability of high quality seeds to farmers at an affordable price. With the rapid increase in demand for maize as an ingredient for animal feed, in recent years, the private sector has shown interest in partnering with farmers to produce maize particularly under contract farming arrangements. Evidences from Sri Lanka show that the smallholder farmers can benefit from contract farming arrangements with private sector companies (Esham et. al., 2005). Therefore, the government should provide incentives to the private sector to enhance their role as partners in contract farming schemes involving smallholder farmers.

\section{Conclusions and Policy Implications}

The aim of this study was to analyze the determinants of productivity variability in smallholder maize production in Sri Lanka. This was achieved by determining the efficiency of smallholder maize farmers and identifying the determinants of inefficiency. A stochastic frontier model was employed on cross sectional data covering a randomly sampled 104 smallholder maize farmers in the Moneragala district. Such empirical analysis is of particular interest in light of the drive of the government of Sri Lanka to expand maize production in the country. Findings indicate that of the five variables used in the production frontier model three comprising of purchased seed cost, hired labor cost and land extent are statistically significant implying that production can be increased by expanding these inputs. Land extent is the single most important factor of production with an elasticity of 0.658. This implies that through consolidation of fragmented land holdings of smallholder farmers' maize production can be significantly increased. The policy implication of this finding is the need for a proper mechanism to bring farmers together as collective farmer groups so that economies of scales can be achieved in maize production.

The mean technical efficiency was $72 \%$ indicating that there is considerable room for improvement in the utilization of inputs. Maize farms can increase their output performance almost by $28 \%$, given the present state of technology. The technical inefficiency analysis reveals that technical efficiency is positively associated with younger age of farmers implying that younger farmers are more inclined to adopt new technology. The significance of the variables such as use of hybrid seeds and ownership of irrigated lowland indicates that only farmers who are better off in terms of their income are entirely using hybrid seeds, while other farmers use a mix of hybrid and local seeds. The high level of statistical significance of the variable, use of hybrid seeds shows the need to make hybrid seeds affordable to farmers, particularly for smallholder farmers. In this regard, policy intervention is needed to provide credit facilities at a reasonable interest rate as well as to increase high quality local hybrid maize seed production as currently the bulk of local hybrid seed requirements are met through imports. Moreover, the government should support the private sector to expand the existing contract farming schemes to remote rural areas. Such policy interventions will ensure increased participation of resource poor smallholder farmers in the maize production drive.

\section{Acknowledgement}

The author is grateful to agriculture extension officers and maize farmers in the study area for participating and supporting the field survey. 


\section{References}

Amarasinghe, S.T.C. \& Weerahewa, J. (2001) An assessment of technical efficiency of potato production. Tropical Agricultural Research, 13, 292-300.

Anupama, J., Singh R.P. \& Kumar, R. (2005) Technical efficiency in maize production in Madhya Pradesh: estimation and implications. Agricultural Economics Research Review, 18(2), 305-315.

Basnayake, B.M.J.K. \& Gunaratne, L.H.P. (2002) Estimation of technical efficiency and its determinants in the tea small holding sector in the mid country wet zone of Sri Lanka. Sri Lankan Journal of Agricultural Economics, 4(1),137-150.

Battese, G. E. \& Coelli, T. J. (1995) A model for technical inefficiency effects in a stochastic frontier production function for panel data. Empirical Economics, 20(2), 325-332. DOI:10.1007/BF01205442

Coelli, T.J. (1996) A guide to frontier version 4.1: A computer program for stochastic frontier production and cost function estimation. Mimeo, Department of Econometrics, University of New England, Armidale.

Department of Census and Statistics of Sri Lanka, (2014). [Online] Available: http://www.statistics.gov.lk/agriculture/seasonalcrops ISeasonalCropsNationalTotals.html June 14, 2013

Esham, M., Usami, K. Kobayashi H. \& Matsumura, I. (2005) Determinants of Farmers' Participation in Farmers-Agribusiness Linkage and Its Implication for Income Distribution in Sri Lanka Case Study of Hybrid Maize Production. Journal of Rural Problems, 41: 200-205.

Esham, M. (2009) A comparative study of farmers-agribusiness linkage in Sri Lanka. American-Eurasian J. Agric \& Environ Sci, 6(5), 591-599.

FAOSTAT, (2014). Agricultural production data, Food and Agriculture Organization of the United Nations. [Online] Available: http://faostat.fao.org/site/567/default.aspx\#ancor (March 10, 2014).

Korovkin, T. (1992) Peasants, grapes and corporations-the growth of contract farming in a Chilean community. The Journal of Peasant Studies, 19(2), 228-254. DOI: 10.1080/03066159208438479

Key N. \& Runsten, D. (1999) Contract farming, smallholders and rural development in Latin America: the organization of agro-processing firms and the scale of out grower production. World Development, 27(2), 381-401. DOI: 10.1016/S0305-750X(98)00144-2

Livestock statistical bulletin, 2012. Department of Animal Production and Health, Sri Lanka. [Online] Available: http://www.daph.gov. Ik/web/images/pdf/stb512012.pdf (June 15, 2013)

Naqvi, A., Syed A. \& Ashfaq, M. (2013) Technical efficiency analysis of hybrid maize production using translog model case study in District Chiniot, Punjab (Pakistan). Agricultural Sciences, 4(10), 536-540. DOI: org/10.4236/as.2013.410072

Shantha, A.A., Asan, A.B.G.H. \& Bandara, R.A.G. (2012) Efficiency and managerial ability of paddy farming under minor irrigation conditions: a frontier production function approach. The Journal of Agricultural Sciences, 7(3),145-158.

Rahman, S., Rahman M. S. \& Rahman, M. H. (2012) Joint determination of the choice of growing season and economic efficiency of maize in Bangladesh. Journal of the Asia Pacific Economy, 17(1), 138-150. DOI:10.1080/13547860.2012.640016

Singh, S. (2002) Contracting out solutions: political economy of contract farming in the Indian Punjab. World Development, 30(9), 16211638. DOI: 10.1016/S0305-750X(02)00059-1

Weatherspoon, D. \& Reardon, T. (2003) The rise of supermarkets in Africa: Implications for agrifood systems and the rural poor. Development Policy Review, 21(3), 333-356. DOI: 10.1111/1467-7679.00214 